УДК: 94(477+470+571),2014/2017”

БУРАКОВ Ю. В.

СУХИЙ О. М.

\title{
СУЧАСНА РОСІЙСЬКО-УКРАЇНСЬКА ВІЙНА У СПОГАДАХ УЧАСНИКІВ - КУРСАНТІВ НАЦІОНАЛЬНОЇ АКАДЕМІЇ СУХОПУТНИХ ВІЙСЬК ІМЕНІ ГЕТЬМАНА ПЕТРА САГАЙДАЧНОГО
}

Аналізуються результати проведеного опитування методом усної історії глибинного інтерв'ю курсантів Національної академії сухопутних військ учасників сучасної російсько-української війни. В інтерв'ю курсантів учасників війни звернена увага на різноманітні аспекти перебування захисників Вітчизни на фронті. Підкреслено значення методу усної історії для створення джерельної бази історичних досліджень 3 новітньої історії України, зокрема 3 історії сучасної російсько-української війни.

Ключові слова: агресія Російської Федерації, Антитерористична операція, АТО, російсько-українська війна, Збройні Сили України, усна історія.

Постановка проблеми та ї̈ актуальність. За останні чотири роки події російсько-української війни є центральними у житті країни. Навіть пережите під час Революції Гідності (осінь 2013 зима 2014 рр.) вже сприймається не як окреме громадське волевиявлення, а радше як одна з причин збройного конфлікту на Сході України.

Життєві історії більшості оповідачів, курсантів - учасників війни на Сході України, пов'язані з подіями, пережитими на фронті. Розповіді про перебування на Сході України й службу військовиків в умовах ведення бойових дій дозволяють доповнити розуміння сучасних подій. За деякий час матеріали інтерв'ю із учасниками АТО стануть у нагоді при формуванні офіційної пам'яті про збройний конфлікт, розпочатий агресією Російської Федерації проти України у лютому 2014 року.

Бураков Юрій Васильович, кандидат історичних наук, доцент, провідний науковий співробітник Наукового центру Сухопутних військ, Національна академія сухопутних військ імені гетьмана Петра Сагайдачного м. Львів.

Сухий Олексій Миколайович, доктор історичних наук, професор, провідний науковий співробітник Наукового центру Сухопутних військ, Національна академія сухопутних військ імені гетьмана Петра Сагайдачного м. Львів.

(C) Бураков Ю.В., Сухий О.М., 2018 
Метою статті є аналіз матеріалів інтерв'ю з військовиками учасниками російсько-української війни, які навчаються у Національній академії сухопутних військ імені гетьмана Петра Сагайдачного (далі - НАСВ). Задум даного інтерв'ю полягав у записі спогадів та міркувань учасників Антитерористичної операції (АТО). Серед обраних респондентів були як військовослужбовці, мобілізовані на військову службу, бійці добровольчих формувань, так і волонтери, які перебували у зоні АТО з березня 2014 року й дотепер.

При домовленості про запис організатори дослідження пояснювали, що отриману інформацію буде використано виключно в науково-дослідних цілях, а не для популяризації окремих сюжетів у 3МI.

Історіографія проблеми. Вперше запроваджено випуск матеріалів усної історії сучасної російсько-української війни у Запорізькому національному університеті. На сьогодні вийшли три випуски збірника. Перший випуск серії 3 історії війни побачив світ у жовтні 2015 року [1]. До нього увійшли шість інтерв’ю, записаних у серпні 2014 - лютому 2015 рр. Другий випуск став вузькотематичним і зосередився лише на 55-й окремій артилерійській бригаді [2]. Мова йде як про значення артилерії в умовах повномасштабних бойових дій, так і про комплектування бригади практично повністю місцевими запорізькими військовослужбовцями. Допомога командування бригади дозволила запорізьким дослідникам опитати більшість військових, що брали участь у знаменитих боях за Донецький аеропорт. Це, безумовно, створює підгрунтя для більш об'єктивного погляду на війну. Третій випуск серії «Усна історія російсько-української війни 2014-2016 років» став важливою віхою у розвиткові проекту [3]. Він засвідчив, що ініціатива вчених вийшла на системний рівень і почала трансформуватися у повноцінний науковий напрям.

Автори запорізького дослідження відзначають: «Важливою проблемою стало оприлюднення зібраних матеріалів... Усі опитувані розповідали про події, що відбуваються сьогодні й пов'язані 3 триваючим військовим конфліктом. Публікація інтерв'ю могла зробити людину мішенню для проросійських терористів...» [3, 12].

Одним із напрямів діяльності Інституту історичних досліджень, створеного у 1992 р. для реформування дослідження і викладання історії у Львівському національному університеті ім. І. Франка, 
$\epsilon$ впровадження нових методів історичних досліджень, зокрема й усної історії. 31996 р. Інститут регулярно видає свій науковий журнал «Україна модерна», в якому публікуються статті, розвідки, рецензії українських та зарубіжних учених 3 історії України та Центрально-Східної Свропи нової й новітньої доби. Один із номерів цього видання (№ 11, 2007) присвячений усній iсторії. 3 кінця 1990-х років Інститутом історичних досліджень реалізовано низку дослідницьких проектів, у яких використовувалася методика усної історії [4].

До розробки методу усної історії долучилися також вітчизняні дослідники Г. Грінченко [5], Т. Величко [6], Т. Пастушенко [7], спільна робота двох останніх авторів [8], Кісь О. [9], Ю. Бураков [10], В. Склокін, I. Реброва [11] та ін., які стосувалися інших сторінок вітчизняної історії, однак окреслюють шляхи розробки усноісторичних досліджень.

Матеріали опитування курсантів-учасників АТО зберігаються у НАСВ. Інтерв'ю за розробленим опитувальником проводили викладачі та науковці Академії [12].

Виклад основного матеріалу. Поглиблене інтерв'ю 3 оповідачами - курсантами НАСВ проводилися за такими блоками: біографічні дані, міркування про особисте ставлення до військового конфлікту на Сході України та участь у ньому, уточнюючі запитання. Перед записом запитували в оповідача, чи є окремі сюжети, до яких не варто звертатись під час розмови або ж вони відносяться до інформації з грифом «таємно» й не підлягають розголошенню.

Розповідь про участь у збройному конфлікті займала домінантну частину інтерв'ю, хоч їй передували окремі міркування про життя інформанта під час Революції Гідності, призову на військову службу, відрядження в зону АТО тощо. При опитуванні свідомо інтерв'юери ставили мінімум питань для того, аби співрозмовник міг самостійно відтворити своє бачення війни та іiі місце у власному житті.

У ході проведеного інтерв'ю 3 курсантами - учасниками війни, отримані такі результати: пересічний вік курсантів коливається між 19 і 29 роками. Найбільше учасників у віці 21-го року. Надзвичайно широка географія місць, з яких вони походять: м. Первомайськ Миколаївської області; м. Кам'янка-Бузька Львівської області; м. Дніпро; м. Яворів Львівської області; 
м. Марганець Дніпропетровської обл.; м. Бердичів Житомирської області; село Криют Новоукраїнського району Кіровоградської області; м. Броди Львівської області; м. Коростишів Житомирської області та ін.

За родом заняття до проходження військової служби курсантиреспонденти поділилися наступним чином: військовослужбовець за контрактом (той, якому виповнилося 29 років); навчався в школі (той, якому - 19 років); строкова служба в армії; вчитель музики, навчалися в училищі; керуючий малого підприємства; студент коледжу та ін.

У графі: «Яким чином і коли потрапили на службу до ЗСУ (доброволець/контрактна служба/мобілізація/) респонденти дали наступні відповіді: підписав контракт до 3СУ; контрактна служба; доброволець, на службу до лав ЗСУ потрапив 31 липня 2014 р.; контрактна служба - батько військовослужбовець і тому я також вирішив бути таким, як він і захищати рідну Батьківщину; доброволець 2014-2015 pр.; на початку війни мій батько пішов добровольцем, але оскільки він частково придатний до військової служби, йому сказали, що відкладуть призов; так як мій батько зразок для мене, я через рік підписав контракт (вік 21 рік) перевівся із строкової служби на контрактну; 30 липня 2014 р. вступив до Військового коледжу сержантського складу при НАСВ, а 28 лютого 2017 р. підписав контракт; з 28 січня 2015 року за мобілізацією у ЗСУ.

Графа «Чи проходили навчання перед відправленням в зону ATO? Де і скільки часу навчалися?» дає уявлення щодо рівня військової освіти і підготовки учасників АТО: проходив навчання 328 січня 2015 р. до 27 лютого 2015 р. у частині п/п B4264 на Яворівському полігоні; навчання проходив у Військовому коледжі сержантського складу при НАСВ у м. Львові; перебував на строковій службі - номер обслуги на гарматі; навчався два місяці на Яворівському полігоні; проходив вишкіл у тренувальному центрі на 33 полігоні - «Десна»; 2 місяці проходив навчання у навчальному центрі «с. Вербляни»; навчався заочно 4 роки у Придніпровській академії будівництва та архітектури, а звідти як доброволець пішов у ЗСУ; місяць часу на Яворівському полігоні с. Старичі; проходив навчання спочатку в «Десні», а потім півроку навчання на полігонах.

На запитання: «Що у Вашому розумінні включає в себе поняття «Батьківщина/Україна»? респонденти відповіли так: «Україна це наша держава, де державною є українська мова»; «дім, сім'я, 
рідні, земля, побратими»; «це земля, де я народився і живу, де живуть мої батьки, бабуся, дідусь, це моя земля і ніхто на ній не буде інший, крім мене»; «Україна - це самостійна незалежна держава. Земля моїх предків»; «Рідна земля, місце, де я народився»; «Це та Батьківщина, де я живу, яку обороняю, яка дає нам віру в себе»; «Рідний край, в якому я народився і живу»; «Україна - де проживаєш і хочеш надалі в ній проживати».

Важливим $є$ запитання інтерв'ю: «Як Ви можете розтлумачити словосполучення «захисник Батьківщини/України»? Воїни витлумачили це запитання наступним чином: «людина, яка в будь-який момент зможе стати на iї захист»; «це той, хто попри всі негаразди буде захисником своєї Батьківщини»; «захисник, який в зоні АТО покладе своє життя заради Батьківщини»; «той, хто боронить територіальну цілісність та народ України»; «це той, хто боронить і покращує ситуацію в країні як фізично на фронті, так і політично-громадськими діями»; «це людина, яка взяла автомат в руки і пішла захищати свою Батьківщину від ворогів, вона не здасть зброю, не підніме білий прапор, буде стояти до кінця»; «людина, яка не жаліє себе, цінує життя своєї сім'ї, товаришів, рідних, цінує свою землю, волю. Готовий віддати своє життя»; «на мою думку, кожен чоловік має бути військовим, щоб могти захистити нашу Батьківщину, свободу».

Аналіз програми поглибленого інтерв'ю показує, що найменше воїни подали інформації у графі «Військово-політична ситуація в Україні (у березні 2014 р. й дотепер). Більш поглиблено відповідали на питання: «Чи змінилось Ваше бачення сучасного воїна iз початком військового конфлікту на Сході України?» Відповіді: «не змінилося; так змінилося - військова підготовка усіх військовослужбовців змінилася у кращий бік; ні не змінилося ми всі фахівці у своїй справі в зоні проведення АТО - ми всі однакові, що офіцери чи рядові солдати, військова батарея як одна велика сім'я; я вважаю, що наша армія стала діяти набагато результативніше».

Особливо важливими є відповіді респондентів на запитання: «Як можете оцінити проведення Антитерористичної операції в Україні з березня 2014 р. й дотепер?». Відповіді воїнів наступні: «В 2014 р. я ще не служив, але мені розповідали, що військо було не укомплектована як слід, тепер ми трохи більш укомплектовані, хоча все рівно велика частина допомоги надходить від волонтерів як і в 14-у, так і тепер. Оцінка бажає бути кращою»; «Судячи 3 
інформації, яку я маю, то оцінка позитивна. Завдяки патріотам, добровольцям ми стримали агресора і тримаємо позиції до цього моменту»; «Початок проведення АТО був дуже важкий через нестачу майже усіх потрібних засобів, але завдяки волонтерам i реформам у нашій армії стан набагато поліпшився»; «змінився в кращий бік, тому що на початок АТО не було ресурсів та досвіду деяких командирів, начальників».

Принципово важливим для характеристики морально-політичного стану воїнів $є$ відповідь на запитання: «За що воюють хлопці на Сході України? Якими, на Вашу думку, є їхні мотиви перебування там?». Відповіді були наступними: «За мир і спокій на всій Україні, за сьогоднішне і майбутнє наших дітей, за свою землю»; «хлопці на Сході воюють за незалежність нашої держави, адже всі ми патріоти своєї країни і вони навіть ціною свого життя будуть їі захищати до нашої перемоги»; «за неньку Україну, за те щоб сім'я була захищена, щоб українська людність не страждала від насильства російського народу»; «мотив полягає у тому, що ми зобов'язані боронити кордони нашої держави, нашу землю»; «всі люди є особистостями, які переслідують свої цілі і мають свої мотиви. Хтось ішов самоствердитись, хтось 3 палкою ідеєю захищати свою землю, а хтось - бо змусили. На початку війни це були в основному ідейні мотиви та патріотизм, а нині, на жаль, стало більше «заробітчан», які прийшли за грошима» (респонденту 25 років і він доброволець); «щоб захистити свої сім'ї, свої будинки від росіян, щоб не прийшли росіяни і не гвалтували наших жінок, не виганяли українців з будинків, щоб наші діти спокійно спали і не знали, що таке війна; сім'я, дім, воля, правда, мир, розвиток, краще життя, побратими; за Україну та за український народ».

Не впоралися воїни із запитанням «Як оцінюєте логістику українського війська»? Відповідали вони на це питання досить мляво, пропонувалося оцінити логістику за п'ятибальною шкалою: «на тверду трійку з плюсом»; (без відповіді); «оцінка - 3 (за 5-ти бальною системою); «дуже добре»; «оцінюю в періоди 2014-2015 - задовільно, 2016-2017 - добре; «на 33 плюсом». Ймовірно це запитання респонденти до кінця не зрозуміли.

Наступне запитання пов'язане 3 мирною професією, чи іiі відсутністю в учасників АТО. Відповіді були такі: «Механікводій категорії В, C; студент заочної форми; керуючий малим 
підприємством; навчався (тобто спеціальності ще не було); працював будівельником; музикант; працював у колгоспі; пекармукосій на місцевому хлібзаводі тощо».

Більш розлогі відповіді респонденти дали на питання: «Чим було обумовлено Ваше рішення поїхати в зону бойових дій? Чи ставили Ви перед собою певну мету або ж ціль, збираючись у таку поїздку?» Відповідь: «Я не ставив певну мету, я просто хотів допомагати нашим побратимам»; «патріотизм, сім'я, рідні, дім, ціль - боронити рідних і землю від загарбників, а також, щоб рідні не відчули весь той жах війни»; «мені хотілося їхати туди, бо там воював мій батько. Не задумуючись, я погодився їхати»; «моєю ціллю були: захист своєї землі, не допустити поширення агресії в інші області; повернення окупованих земель та відновлення рівноваги і порядку; «я вважаю, що кожен хто хоч раз одягнув форму, зобов'язаний прийняти участь у бойових діях»; «ціль була знищити російських бойовиків і Путіна»; «там, тому що я захисник своєї Батьківщини і це мій обов'язок. Я хотів зробити усе, що в моїх силах, зробити свій внесок»; «нічим не було обумовлено. Ціль була одна - захист своєї Батьківщини».

Більш розлогі відповіді респонденти давали також на запитання: «Як склалася Ваша дорога на фронт»: «Зі Львова ми поїхали до Хмельницького поїздом, потім 3 Хмельницького у Рубіжне, далі автобусом з Рубіжного до міста Щастя»; «не можу розповісти, бо емоції словами не передати. А в цілому дорога була складною і болісною»; «ми їхали три доби, дорога сильно виснажила, але це все не забирало в мене бажання їхати в АТО. Зі мною були мої бойові товариші, які підтримували один одного»; «Дорога була веселою. Хлопці, які були там раніше розповідали виключно позитивні моменти служби в зоні, а до «негативних звикнеш» - говорили вони. А вже в Красному Лимані, в кубрику, де я відпочивав залетів камінь! Так нас зустрічали»; «без пригод»; «переміщення в складі підрозділу потягом»; «нормально».

На питання, пов'язане із повсякденним життям на фронті: «Розкажіть про розпорядок дня, режим, житлові умови, атмосферу Вашого перебування в зоні бойових дій». Відповіді були такі: «о 6-й годині був підйом, потім мились, снідали, а якщо стріляли, могли добу не спати - дві доби, жили в бліндажах, сараях; підйом, сніданок, робочі моменти (підготовка позицій, зброї, техніки), робота 3 особовим складом. Житлові умови 
окопно-бліндажні»; «розпорядок дня: зранку підйом о 8-й, сніданок 8.30, шикування 9. Після обіду і протягом усього дня займалися роботою - маскування техніки, копали окопи, відправлялись на склади складати боєприпаси; дехто в нарядах стояв, рубали дрова, щоб розпалювати буржуйки. Жили в колишньому піонерському таборі, умови були нормальні. Ми собі зробили все можливе для проживання. Пили деякий час воду 3 річки, пізніше почали привозити в бутлях»; «вдень ми могли вільно пересуватися по посадці, піти поїсти, готували техніку до темряви. А десь після 22-ї ми виїжджали в зону, де ведуться бойові дії. Цілу ніч бойове чергування, як настає світанок ми поверталися назад і знову готувалися до ночі»; «дуже добре, як вдома, аби годували краще, дуже швидко звикаєш до повсякденного життя»; «підйом, сніданок, розвід на роботи. Житлові умови були добрі, адже самі їх собі зробили, Атмосфера постійного напруження»; «розпорядок дня, як і в частині, були зміни. Житлові умови різні, атмосфера перебування - нормальна».

Наступне запитання: «опишіть як Ви там одягалися? Чи перебували у бронежилеті та шоломі?». Відповідь: «Одягався в те, що видали ЗСУ, а також, що придбав за свій кошт, тому що в зимових берцях літом не дуже комфортно і форма зношується швидше. Носив і бронежилет, і шолом»; «одягнутий в українську форму одягу, завжди в бронежилеті та шоломі, крім робіт 3 технікою, в яких вони заважали»; «деколи одягав, деколи ні. Коли стріляли по російських бойовиках, то не одягав, він був зайвий, заважав, а на постах, в наряді одягав»; «одягав літом наш український піксель, а на зиму волонтери забезпечували нас теплим одягом. На позиціях бронік та каска - це обов'язкове»; «одягалися по погоді. Так, броню і шолом на позиціях носили постійно»; «одягався: штани, кітель, кофти під кітель, щоб було тепло, бо зима була дуже холодна, в нарядах було дуже холодно. В нарядах перебував у бронежилеті і касці»; «форма одягу волонтерське забезпечення формою (різного типу). Бронежилет $\mathrm{i}$ шолом лише під час бою, на бойовому чергуванні, а також на бойових виходах та штурмах»; «бронежилет навіть і не знімали. Хіба, коли йшли на обід, на вечерю, могли зняти бронежилет, коли їхали в місто. А коли заступали в наряд на блокпост, то там ніколи не знімали». Відповіді на це запитання засвідчують, що воїни зацікавлено розповідають про свої будні та засоби безпеки. 
Наступне запитання стосується морального клімату у військовому середовищі. Запитання: «Чи зверталися до Вас по допомогу інші військовослужбовці? Як Ви їм допомагали?». Респонденти дали наступні відповіді: « До мене не зверталися про допомогу, бо в нас був замполіт, який всім допомагав»; «так, зверталися. Допомагав фінансово, електротехнікою, надавав медичну допомогу, технічну допомогу, морально-психологічну, допомагав 3 житлом»; «ми були як сім'я, всі один одному допомагали, не було такого, щоб хтось чогось не знав чи не розумів»; «зверталися новачки, які до нас приїжджали. Був цікавий випадок під Авдіївкою. Був день, було затишно, мороз сильний. Ми сиділи біля вогню і сушили речі. Я подивився на годинник і кажу: «Давайте хлопці в укриття, бо вже вечоріє! Пішов. Вони не звернули уваги, так як не зрозуміли до чого я те сказав. Але не пройшло й 10 хвилин, як всі, хто ослухався, завалились на мене зверху в окоп і очі у них були по 5 копійок»; «звертались. Надавав грошову допомогу»; «звертались. Чим міг то допомагав»; «Зверталися. Допомагав порадою у вирішенні їхнього питання».

Наступне запитання: «Як Ви спілкувалися 3 бійцями свого підрозділу протягом дня?» Відповіді: «дуже добре, були і жарти і сварки, і знову мирилися»; «намагався підтримувати колективізм у розрахунку. Після того, як всі звикли, то на позиціях звучали анекдоти і т.ін.»; «це в основному суто побутові питання»; «нормально спілкувались, всі були дружні»; «спілкування на одному рівні, з повагою один до одного»; «добре спілкувалися, коли стріляли допомагали один одному, прикривали».

Наступне запитання стосувалося побутового облаштування в підрозділах: «Чи залучали Вас до окремих робіт по облаштуванню підрозділу? Якщо так, то яких саме?». Респонденти надали наступні відповіді: «мене не залучали до робіт»; «моральнопсихологічні роботи, облаштування бліндажів, а також пункту прийому i зберігання їжі»; «залучали до маскування техніки, облаштування житла, окопів, КПП»; «облаштування житлових бліндажів та приміщень. Будівництво фортифікаційних споруд та укриттів»; «облаштування бліндажів в зоні відведення, підготовки гармати до бойової роботи»; «так залучали. Рили і облаштовували бліндажі, будували баню, їдальню, пиляли і рубали дрова»; «залучали до облаштування житла, позицій, постів»; «Залучали. Копали і облаштовували бліндажі, виконували інші роботи». 
Таким чином, проаналізувавши спогади учасників АТО, можна зробити певні висновки. Події, які переживає народ України упродовж сучасної російсько-української війни ще раз засвідчили, що проголошена у 1991р. державна незалежність потребує постійного захисту, глибокого розуміння та оцінки того, що відбувається навколо нас. Саме тому на лекція та семінарських заняттях курсантів, присвячених сьогоденню, особлива увага повинна приділятися ролі учасників бойових дій на Сході України та волонтерам. Викладачі мають грунтовно опрацювати терміни «патріотизм», «нація», їх розуміння курсантами. Необхідно акцентувати увагу на тому, що патріотизм сьогодні проявляється не лише в безпосередній боротьбі на Сході із зовнішнім ворогом, не тільки в надзвичайних ситуаціях, але $\epsilon$ звичайним станом повсякденного життя людини. Рекомендується широко використовувати документи, спогади, кіно- i фотоматеріали, звукозаписи, художні твори, які допоможуть створити на заняттях 3 курсантами відповідну емоційну атмосферу, підсилять виховний вплив навчального матеріалу.

Вважаємо, що дослідження у галузі усної історії серед курсантів - учасників війни повинні тривати й надалі. Такі дослідження сприяли би накопиченню, опрацюванню та введенню у науковий обіг джерел усної історії; розробці тематичних курсів та навчальних програм для студентів вищих військових навчальних закладів. Слід розширяти та впорядкувати базу інтерв'юерів, курсантів - учасників сучасної російсько-української війни і в наступні роки.

1. Усна історія російсько-української війни (20142015 роки) / за ред. В. Мороко; Укр. ін-т нац. пам'яті, Запоріз. нац. ун-т., Іст. ф-т, Запоріз. облдержадмін., Департамент культури, туризму, національностей та релігій. - Вип. 1. Київ: К.І.С., 2015.

2. Усна історія російсько-української війни (20142015 роки) / за ред. В. Мороко; Укр. ін-т нац. пам'яті, Запоріз. нац. ун-т., Іст. ф-т, Запоріз. облдержадмін., Департамент культури, туризму, національностей та релігій. - Вип. 2. Київ : К.І.С., 2016.

3. Усна історія російсько-української війни (20142016 роки) / за ред. В. Мільчева та В.Мороко - Вип. 3. Київ : К.І.С., 2016.

4. Україна Модерна, часопис, число 11, рік 2007 / Електронний ресурс: http://uamoderna.com/arkhiv/46-11.

5. Грінченко Г. Усна історія: Методичні рекомендації 3 організації дослідження: для студентів і аспірантів. Харків: Харківський нац. ун-т ім. В.Н. Каразіна, 2007; Невигадане. Усні історії остарбайтерів / Ред., вступ. ст. Г. Грінченко. - Х., 2004. 
6. Величко T. Всеукраинская летняя полевая школа по устной истории «Холокост глазами нееврейского населения (русских, украинцев, крымских татар) на примере Крымского полуострова // Голокост і сучасність. - 2007. - № 1.

7. Пастушенко T. Метод усної історії та усно історичні дослідження в Україні // Історія України. - 2010. Вип. 17-18. - С. 10.

8. Величко T., Пастушенко T. Польові школи з усної історії «Голокост очима неєврейського населення України» // Схід/Захід: Іст.-культ. зб. / Схід. ін-т українознавства ім. Ковальських та ін. - Вип. 11-12: Спец. вид.: Усна історія в сучасних соціально-гуманітарних студіях: теорія і практика досліджень. - Х., 2008.

9. Кicb O. Усна історія: становлення, проблематика, методологічні засади // Україна модерна. - 2007. - № 11.

10. Бураков Ю. Усна історія: участь радянських військовослужбовців у війні в далекій Анголі/ Людина i техніка у визначних битвах XX століття: Збірник тез доповідей Міжнародної наукової конференції 15-17 червня 2017 р. - Львів: НАСВ, 2017, с. 61-63.

11. Склокін B., Реброва I. Усна історія в Україні: заповнення «білих плям» чи методологічний переворот? // Схід/Захід: Іст.-культ. зб. / Схід. ін-т українознавства ім. Ковальських та ін. - Вип. 11-12: Спец. вид.: Усна історія в сучасних соціально-гуманітарних студіях: теорія і практика досліджень. - Х., 2008.

12. Поточний архів науково-дослідної лабораторії (військово-історичних досліджень) Наукового центру Сухопутних військ Національної академії сухопутних військ імені гетьмана Петра Сагайдачного, ф.1, оп.2, спр.1.

Надійшла до редколегії 25.12.2017 p.

Рецензент: Терський C.B., доктор історичних наук, професор, професор кафедри історії, музеєзнавства та культурної спадщини Національного університету «Львівська політехніка», м. Львів.

\section{Burakov Yuriy, Sukhyi Olexsiy \\ RUSSIAN-UKRAINIAN MODERN WAR IN MEMORIES OF PARTICIPANTS - CADETS OF HETMAN PETRO SAHAIDACHNYI NATIONAL ARMY ACADEMY}

The article analyses the results of the interview by means of the method of oral history - a depth interview with the cadets of the National Army Academy participants in the present-day Russian-Ukrainian war. During the interview with cadets - participants of war a great attention was paid to various aspects of the defenders of Ukraine serving at the front. Emphasis is made on the significance of oral history for creating a baseline of historical researches on the recent history of Ukraine, in particular, the history of the current Russian-Ukrainian war.

Key words: aggression of the Russian Federation, anti-terrorist operation, ATO, Russian-Ukrainian war, Armed Forces of Ukraine, oral history. 